\title{
Analysis of legislative consolidation and political practice of applying social (juvenile) technologies concerning minors in the Russian federation
}

\author{
Elena V. Portnyagina \\ candidate of political science \\ Omsk State Pedagogic \\ University 644019, \\ Naberezhnaya \\ Tukhachevskogo Str., 14, \\ Omsk, Russia e-mail \\ portnjgina@mail.ru, \\ 89043217719
}

\begin{abstract}
- the author based the research on the hypothesis: in the Russian Federation there is no legislative regulation of the concepts of juvenile (social technologies) in working with minors while using these technologies by separate subjects of state policy concerning minors. Juvenile technologies are considered from the point of view of political practice of the subjects of the Russian Federation.

The purpose of the scientific article: on the basis of the analysis of legislative changes and the practice of applying social (juvenile, innovative) technologies to minors is to show the necessity of development and consolidation of approaches to the implementation of this technology concerning minors as subjects of state policy.

The author uses a synergetic approach that allows us to consider the problem of social (juvenile) technologies as a system of relationships between different political actors who interact as a part of the implementation of the state policy concerning minors; take into account the multiplicity of factors affecting the processes occurring in this process. The approach of political modeling is also applied to predict the perspectives of the development of the juvenile practices in the Russian Federation and their legislative control.
\end{abstract}

The author studies the juvenile technologies as political technologies as a way of fulfilling goals and objectives in the state policy in the field of the rights protecting and legitimate interests of children. In the article, based on a review of the experience of successful juvenile practices in the subjects of the Russian Federation, and analysis of legislative and by-laws of the Russian Federation in the sphere of ensuring the rights and legitimate interests of minors, the necessity of synthesis and replicating of these technologies in the territory of the Russian Federation is proved.

One of the problems the author raises is the lack of mechanisms for interagency interaction and coordination of activities of all subjects of state policy concerning minors. The author suggests appropriate recommendations directed on the optimization of political decisions in this area. The recommendations in particular touch upon the necessity to develop a better evaluation system in the form of indicators for the implementation of the main tasks in the area of state policy on minors through the implementation of juvenile political practices.

Keywords - state policy protecting the legitimate interests of minors, social (juvenile) technologies concerning minors, juvenile practices, interagency cooperation.

\section{INTRODUCTION}

During the latest 10 years, within state policy of protection of interests of the family and the childhood not only legislative activity has been amplified, but also the attempts to construct effective interaction of public authorities with institutes of civil society have been implemented. A large list of legislative and subordinate acts actually reflects the process of politically-right development and the introduction of innovative technologies in Russia of the juvenile nature, but at the same time, has no complete system and legitimate character.. The main issue at present time in the considered direction of state policy is the search of effective technologies in protecting the rights and legitimate interests of minors.

Within the research the author offers to consider social state policy concerning minors as the set of measures and social (juvenile) technologies of public authorities and municipal units within the established competence directed on creating the favorable environment for physical intellectual, mental, spiritual and moral development of children and also protecting against the factors of the social environment having negative effect on their development, support in a difficult life situation. (circuitry 1.)

Political technologies in political science are understood as set of methods, ways of impact on subjects, by means of these methods political goals are achieved.. [1] 
In relation to juvenile technologies this concept demands specification. First, juvenile technologies do not only include a set of methods and ways of influence, technology has a long implementation time for the same target audience and should be completed by monitoring the quantitative and qualitative indicators developed in advance. It demands assessment of the efficiency as this technology is focused on social effect Secondly, in the context of political technology about juvenile technologies; we need to specify the purpose of impacting political actors. In our understanding the purpose will be to create the environment which solves those political tasks that are set by state policy concerning family and the childhood as priority directions. Development of a scientific thought concerning a research of concepts "innovative", "juvenile technologies" reflects expansion of approaches to their definition [2]

Circuitry 1. Social state policy concerning minors

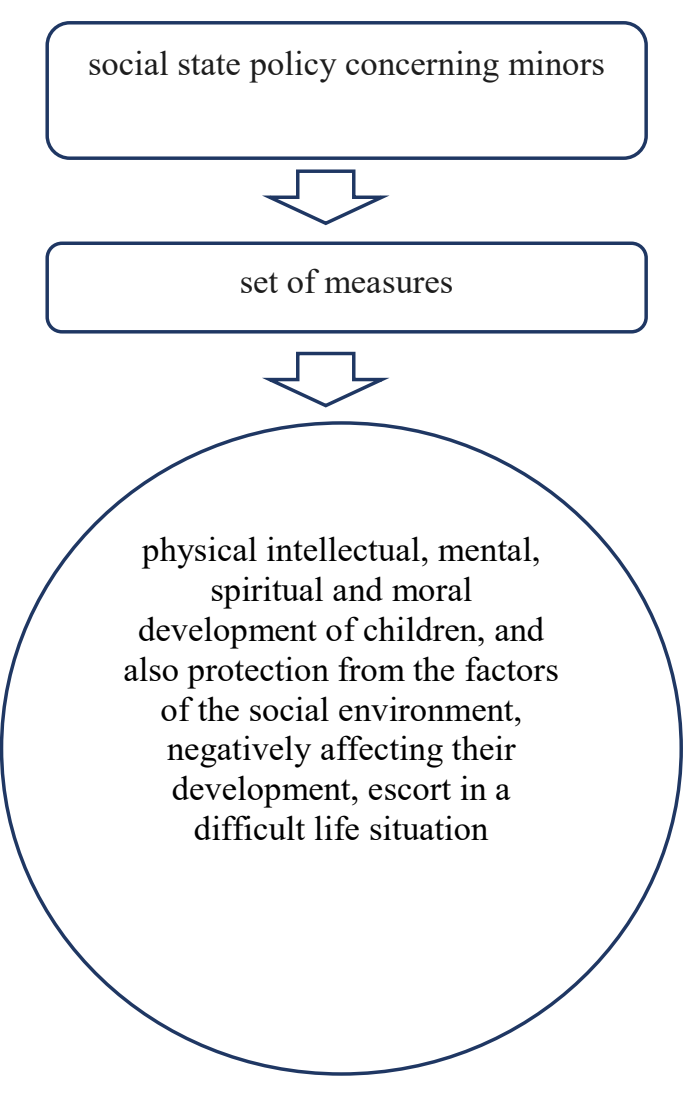

\section{METHODS}

\section{in scientific research \\ Consideration problem of "juvenile technologies"}

The works of Russian jurists in the field of various branch jurisprudence sciences concerning questions of human and citizen rights their implementation and their guarantees among which there are S.S. Alekseev, A.G. Berezhny, N.A. Bobrova, L.D. Voyevodin, S.E. Zhilinsky, L.D. Zlatopolsky's works and others are widely presented in publications of political and legal character. Various aspects of a problem of juvenile justice and creation of system of protecting the rights of the child were investigated by L.I. Belyaeva, V.V. Boytsova, N.E. Borisova, N.A. Bobrova, E.V. Markovicheva, etc. In the context of fulfilling technology of "friendly justice" concerning the minor the article by Levina L.M. and Bokova N.V. is of interest. [3]

Important sociological, pedagogical and psychological problems of cognition of the legal mechanism for protecting the rights and legitimate interests of minors are represented by the research of Terekhina S.V., Pimonov V.A. [4] Budykina S.V., Dvorianchikova N.V., Bovina I.B. [5], Joyko Nikula, N. Ivashnichenko. [6]

Publications of recent years are of particular interest, because themes and approaches in research have changed. are carried out at the interface of law and psychology, that specific nature of juvenile relations and their subjects minors determines. The object of research is not the mechanism for the protection of rights, but technologies for the prevention of social orphanhood, deviant behavior, neglect, juvenile delinquency. This is possible through the adoption of the National Strategy for Children for 2012-2017, approved by Presidential Decree No. 761 on June 1, 2012.. This document reflects the principle of technologization in the state policy concerning minors.

Among the interdisciplinary researches scientific articles by Litvinova A.V., Mirimanova M.S., are of special interest; the object of research was a problem of legal knowledge as a factor of psychological safety of minors. In the context of the formation of such a priority direction as the information safety of minors and the search of political practices and technologies for its implementation, this topic is very relevant. [7]

Certainly, researches in the field of policy of the family search for children without parental support where also we find reflection of technologization of this process from the political point of view, are of scientific interest to us. Among such works the results of a research of Mary Kulmala, Michael Rasell, Zhanna Chernova should be marked.

A particular interest within the research held by the author is represented by a position Yurchuk V.S. and Izmaylova M.V., staticizing problems of a juvenalization of Russian law. The author of this article has mentioned these problems in his publications several times, but from another side - as the part of political technologies and political practices, including the federal subjects of the Russian Federation. [9]

Thus the analysis of scientific publications shows huge interest in a cross-disciplinary problem of state regulation of institute of protection of the minors rights, and first of all finds out necessity of considering political practices of using juvenile technologies in work with various categories of minors, necessity of development of criteria of efficiency of their fulfilling and their including as one of indicators of efficiency of realization of state policy concerning minors at the level of territorial subjects of the Russian Federation. 


\section{RESULTS}

3.1. Analysis of strategic normative acts in the field of protecting the rights and legitimate benefits of minors: change of approaches in public policy .

In author's opinion, the following documents should be concerned as strategically important, firstly, the National Strategy of Action for Children for 2012-2017, and, secondly, the Concept of Information Security of Children. These documents, first of all the strategy of actions for the benefit of children, have defined a vector of political and legal development in the sphere of protection of the rights and legitimate interests of children in the nearest future., The analysis of these documents has shown that technologies and cooperation, social partnership, monitoring are becoming key concepts.

1. The dynamics of legislative regulation of the institution of the protection of the rights and legitimate interests of minors reflects the process of increasing number of normative acts in the sphere of social relations. Before adopting the National strategy of actions for children's benefit during 2012-2017 it was possible to speak about such stage of evolution of the legal framework in the considered sphere as creating the minimal bases according to the international obligations taken by the Russian Federation.. We are talking about the adoption of the Law "Basic guarantees of the child rights", strengthened special social - legal status of children; The Law "About the Basic Points of the System for the Prevention of Neglect and Juvenile Delinquency", strengthening the system for managing these legal relationships; the consolidation of certain chapters in the Labor Code, the Criminal Code. The establishment of institute of the Commissioner on the Children's Rights played an important role

During the period since 2010 we can allocate the following stage in development of state policy concerning minors: creating the standard and legal base focused on creation of the favorable environment for physical, intellectual, psychoemotional development of the children, protection them from negative consequences of hyper information (Federal Law "On Advertising", Federal Law "On Protection of Children from Information Harmful to Their Health and Development, "National Strategy for Children 2012-2017," the concept of information safety of children").

The implementation of new technologies into work with minors and families in general can be described as " technologization of approaches" in the state policy concerning minors and work with them. Problems of state policy gain more and more complete and complex character, the concepts "actions", are replaced by the terms "maintenance", "technologies". In the concept of information security terms "cooperation", "interaction" are actively used assuming necessety for the organization of joint actions, including search of new ways of solutions of objectives in the considered sphere and new technologies together with all caring persons, active attraction of public organizations.. The principle of social partnership enshrined in the concept reflects the state realizing of its necessity for providing the effective solution of national objectives in this sphere. In particular, in the concept it is asked about need of public assessment of efficiency of the applied technologies and mechanisms for the sphere of protection of legitimate interests and rights of the child, for the sphere of creation of the safe environment for his development. In particular, the concept raises the question of need for a public assessment of the effectiveness of the technologies and mechanisms used to protect legitimate interests and rights of the child, the creating safe environment for his development (Circuitry 2).

Circuitry 2.

Technologization of approaches social state policy concerning minors

$\sqrt{\square}$

technologization of approaches social state policy concerning minors

activities, accompaniment, technology, cooperation, interaction

The principle of social partnership

3.2. Analysis of the experience of juvenile technologies (juvenile practices) implementation in selected subjects of the Russian Federation

For the analysis of implementation of juvenile technologies in certain territorial subjects of the Russian Federation the author doesn't take experience of the subjects carrying out pilot projects on realization of technologies of "friendly justice", "juvenile courts", laboratories of juvenile technologies (Rostov-on-Don, Perm, Moscow, St. Petersburg). One of the tasks of implementing the National Strategy of Actions for Children's benefit is the dissemination of successful juvenile practices. Along with change of approaches in state policy, on the basis of the analysis of political practices of territorial subjects of the Russian Federation (the analysis was carried out first of all on the basis of official reports of subjects) and also reviews of methodical materials on implementation of pilot projects in the sphere of introduction of innovative technologies in work with minors, we see widespread development and introduction in political practice of regions of various models of juvenile technologies, technologies of social support. As a rule, these technologies are experimental testing and show the result of interaction between state and (or) municipal government and public, educational organizations.

Analysis of experience in the implementation of juvenile practices in the Omsk region, carried out in the period 2012-2013; 2015-2017 based on the experience in participation in intermunicipal conferences and seminars, as well as participation in arranging and holding of joint 
seminars with state authorities of the Omsk region and municipal authorities in Omsk, whose main task was the process of supporting children who were in difficult life situations, the protection of rights and legal interests of children, including children left without parental care, information support for these categories of children, as well as students from this category, allowed to make the following conclusions. First, in the Omsk region there is a coordinating council under the Commissioner for Children's Rights under the Governor's Office of the Omsk Region, which in particular includes specialists from educational and public organizations specializing in this sphere. In particular, on the basis of the activities of this council, reports on monitoring the implementation of the National Action Strategy for Children in the Subject Territory. are being prepared However, most of the indicators used to prepare the report are quantitative, representing statistics on the implementation and enforcement of legal rights in minors ' benefit. Special attention is payed to certain categories of children according to the National Strategy. Still, the issue of "technologization" of state policy at the level of federal subjects remains open. The analysis of the activities of budget social institutions of the region's districts shows that there is no technologicalization at the policy level, since there is no systematic approach, no implementation methodology, no legislative consolidation of the concept, and no mechanisms for coordination and interaction between all political actors in this matter. At the same time there is a tendency of number increasing of successful juvenile practices in some municipal districts. As an example, the practice of the Novovaravshavsky municipal district of the Omsk region should be mentioned According to social and economic parameters, this is a developing region that attracts young people, creates places for employment, accepts foster families and creates special conditions for them.

In this area, the experience of the social inspectors service is realized, who support not only children, but also families in a difficult life situation. Information work is carried out with families to improve pedagogical and legal literacy. The main problems that district leaders face are:

- lack of personnel. This problem is typical for all municipal districts of the Omsk region and the city as well. There is also lack of specialists with the necessary comprehensive education of psychologist, mediator, and lawyer. The author supposes that this niche should be occupied by Omsk State Pedagogical University. Now, the author participates in the development of a new bachelor's and master's program, providing formation of model of the expert whose aim will be implementing special technologies concerning families, minors appeared in a difficult life situation, in conflict with the law, etc.

- lack of education of parents, including foster families. In this direction, the work is carried out by "target" projects, including specialists of pre-school educational institutions on the topics: "Social adaptation and necessity of intellectual development of preschool children", including the arranging of master classes for parents.
- low level of cash security. Many families cannot allow to pay kindergartens, to pay the road to the nearest educational institution or a centre of support, development of minors, and legal support. (Circuitry 3).

These organizational, personnel, financial problems prevent from the implementing the state policy technologization on minors and make it possible to implement individual projects to different target audiences, still it is rather difficult to monitor their quality influence on these audiences But at the same time, the juvenile practices are most likely to develop at the municipal level. Municipalities with a deficit budget try to "survive" due to the active development of technologies of people attracting to solve local socially important problems. Thus, a social environment where the values of the family, the homeland, and patriotism are formed is created .Local traditions such as "street festival", "parade of professions", "anniversary of the village", in this case are transformed into technology of working with the different aged population, including technologies of education, identification and support of minors, families in difficult life situation.

Circuitry 3

The main problems the district leaders face

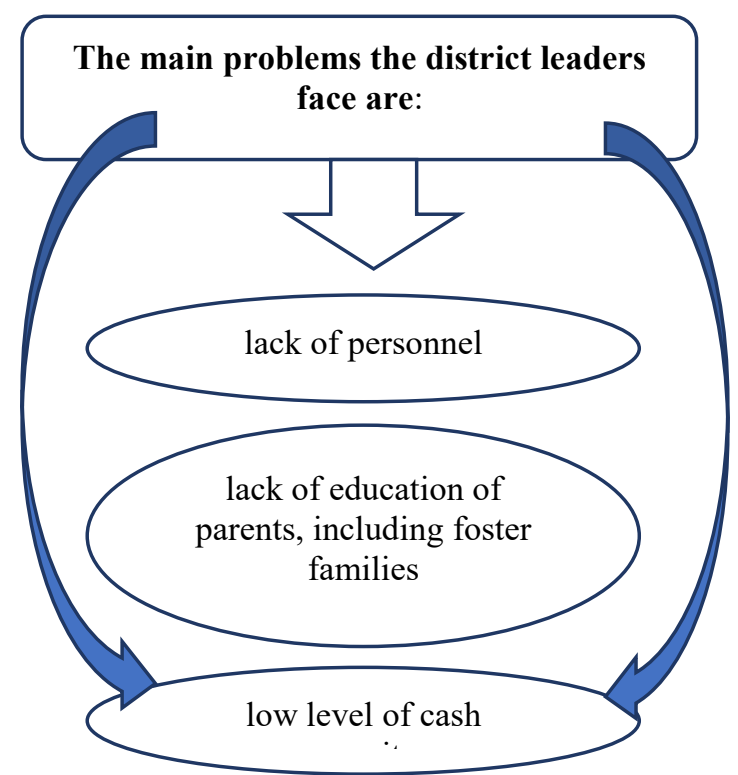

The chronicles of such regular events, describe the methodology, gather statements of residents and their attitude, allow to monitor the dynamics of changes in the life of the target audiences. But these events can become technologies of a specific work only in the case of a scientific description, where the goals, expected results, target audience, effectiveness indicators will be pointed.

And the following problem appears the lack of, academic professionals who could provide a scientific basis for these technologies. Nevertheless, this problem can be solved through social partnerships with regional universities by creating innovative platforms and implementation of 
certain socially significant projects for the implementation of juvenile practices on the territory of the municipality.

If to consider the experience of definite social institutions, then most of the implemented technologies concerning the minors can be described as technologies of a socially pedagogical nature. But these technologies are becoming more complex and require work with minors taking into account their environment, including the family. Thus, any technology of working with a minor is the individual, complex program that can be implemented in dynamics with constant monitoring indicators of changes in qualitative and quantitative characteristics. And this program should have a scientific and legal basis.

Juvenile technologies in the sphere of legal relations with the participation of a minor person were widely spread. The practice of friendly justice is also implemented at the level of testing by certain subjects, though in national strategy of actions for the benefit of children, we see consolidating of this legal circulation in the context of public policy priorities in the interests of children. The experience of friendly juvenile justice in foreign countries (for example the experience of France is very interesting) also considers this technology through the formation of the environment, and assumes the post-judicial support of a minor who is in conflict with the law. [9]

\section{CONCLUSION}

The analysis of the public administration experience in the implementation of public policy concerning various categories of minors, as well as the experience of the activities of public organizations and budgetary institutions in implementing specific juvenile practices and juvenile technologies shows relevance of the problem of confirming of the concepts "juvenile technologies", "juvenile system" at the level of federal legislation.

The topic is highly discussed and the author has repeatedly disclosed the problem of the legitimacy of the concept of "juvenile justice" in relation to all political processes related to the use of juvenile technologies in relation to minors in his publications. According to t V.S. Yurchuk and M.V. Izmaylov the term "juvenile justice" is not used in international law, its subject is a problem of rights protection for the minors` benefit. But the question of defining a category reflecting the specifics of these relations remains open. And the author suggests using the concepts of "juvenile technologies" to describe the specifics of technology in work with minors of various categories, including ones in conflict with the law, or in a difficult life situation, etc. The term "juvenile system" in our opinion could denote the whole system of state and municipal authorities ensuring the implementation of the state policy concerning minors, if at the same time with the list of municipal authorities, in accordance with specific political practices of the subjects, the mechanism of interaction will be consolidated. Development of criteria of efficiency of political practices on implementing juvenile technologies in work of public authorities of territorial subjects of the Russian Federation, $70 \%$ must have qualitative indicators and only $30 \%$ - quantitative ones The analysis of the site, designed to show the efficiency of the National Strategy of Actions for Children Benefit 2012-2017, (http: //xn--clackabuhcbecyrh.xn--p1ai) proves that not all subjects reflect in their reports and fulfill management practice of social (juvenile) technology. Moreover, content analysis shows that only a small fraction of the subjects of the Russian Federation understands the difference between technology and target activities, which are reflected in the "classical" plans of events.

Regional strategies for children repeat the federal strategy. The author supposes that the approval of complex long-term programs reflecting the specifics of technological development of political practices in work with juveniles at the level of subjects should be the result of the adoption of National Strategy. In particular, criteria have been developed for assessing the effectiveness of the used technology.

1. Within the existing legal frameworks, the development of forms of interagency cooperation between state and municipal authorities, subordinate institutions, and public organizations for the implementation of juvenile technologies concerning minors in conflict with the law, in difficult life situations, as well as for the purpose of preventing offenses, neglect, family conflicts, etc. Their purpose should be both the selection of optimal technologies for solving urgent problems in this field and consolidation of the program, where concrete actions of each participant for the implementation of this technology concerning the selected target audience, as well as the efficiency criteria of the program implementation would have been reflected [12]

\section{REFERENCES}

[1] Sokolova R.I., U. Mats, V.I. Spiridonova, Osipova EV Zuev K.A. , Bezruchkin O.L., Burov V.D., Technologia vlasti. Philosovsko-politicheski analys. [Technology of power. Philosophical and political analysis.]. Monograph. Otv. The editor is Ph.D. R.I. Sokolov. - M., Institute of Philosophy of the Russian Academy of Sciences, 1995, Center for Humanitarian Technologies 15.12.2011. URL: http://gtmarket.ru/laboratory/basis/4525.

[2] Portnyagina, E.V., \& Loshchilova M.A. (2016). Juvenile technologies as a system of organisation of social partnership of the state and society. SHS Web of Conferences 28.

[3] Levin L.M., Bokova N. A comparative analysis of the early memories of juvenile offenders who have committed crimes of varying severity [Elektronnyi resurs]. Psikhologiia i pravo [Psychology and Law], 2017. Vol. 7, no. 3, pp. 1-16. doi:10.17759/psylaw.2017070301.

[4] Terekhina S.A., Pimonov V.A. The problems of defending the interests of juveniles in legal cases of domestic disputes during the divorce. [Elektronnyi resurs]. Psikhologiia i pravo [Psychology and Law], 2016(6), no. 1. pp.91104. doi: 10.17759/psylaw.2016060108

[5] Budykin S.V., Dvoryanchikov N.V., Bovina I.B. Information Security of Children and Adolescents According to Parents and Teachers (Part 2: The Results of an Empirical Study). [Elektronnyi resurs]. Psikhologiia i pravo [Psychology and Law], 2016(6), no. 1. pp.25-38. doi: 10.17759/psylaw.2016060104

[6] Jouko Nikula, Nina Ivashinenko foster care reform and social partnership in Nizhny Novgorod reion// The Journal of Social politics Studies. Volume 15. No 3. .P. 383-394

[7] LitvinovaA.V. \& Mirimanova M.S. Pravovaya informirovannost podrostkov kak faktor-psihologicheskoj bezopasnosti obrazovatelnoj sredy [Legal awareness of adolescents as a factor of the psychological safety of the 
educational environment] [Electronic resource] Psychology and law. 2015.

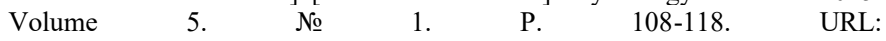
http://psyjournals.ru/psyandlaw/2015/n1/76158.shtml (reference date: June 10, 2017).

[8] Meri Kulmala, Michael Rasell, Zhanna Chernova. Overhauling Russia child welfare system: institutional and ideational factors behind the paradigm shift// The Journal of Social politics Studies. Volume 15. No 3. .P. 353-366 [9] E.V. Portnjagina, Juvenile technologies in Russia: political and legal aspects. In the world of scientific discoveries, Problemy nauki I obrazovanija 11.5 (47), 139-147 (2014).

[10] Yurchuk V.S., Izmailov M.V. Osnovnye podhody k obespecheniyu yuvenalizacii-prava v rossijskoj federacii. Vestnik Moskovskogo Universiteta
[Basic approaches to ensuring the juvenile justice in the Russian Federation. Bulletin of the Moscow University. S.Yu. Witte.] Series 2. Law. 2016. No. 2 (9) pp. 48-57

[11] Shmeleva E. V. Odarennaya molodezh' i razvitie novyh obrazovatel'nyh tekhnologij kak politicheskaya problema. - Polis. Politicheskie issledovaniya. 2018. № 2. S. 29-36.

[12] Terekhina S.A., Pimonov V.A. The problems of defending the interests of juveniles in legal cases of domestic disputes during the divorce. [Elektronnyi resurs]. Psikhologiia i pravo [Psychology and Law], 2016(6), no. 1. pp.91-104. doi: 10.17759/psylaw.2016060108 